\title{
Edukasi Gizi Spesifik Sebagai Gerakan 1000 Hari Pertama Kehidupan (HPK) Dalam Upaya Pencegahan Stunting Balita Pada Siswi di SMK Farmasi Al Furqan Banjarmasin
}

\author{
Khairul Anam ${ }^{1}$ Norfai $^{2}$, Meilya Farika Indah ${ }^{3}$ \\ ${ }^{1,2,3}$ FakultasKesehatan Masyarakat Universitas Islam Kalimantan (UNISKA)MAAB Banjarmasin \\ email:norfai92@gmail.com
}

Submitted : 05/09/2021

Accepted: 16/10/2021

Published: 19/11/2021

\begin{abstract}
The purpose of this service is to transform and increase student knowledge about specific nutrition in the First 1000 Days of Life. The counseling method is carried out with two methods, namely the lecture method and the discussion method that uses media of power points. Before starting the counseling, a pretest activity is conducted on "Specific Nutrition in the First 1000 Days of Life", then after being given counseling, the questionnaire is distributed again to be refilled by female students, after knowledge data, before and after counseling has been obtained, then analyzed using the statistical test Paired Sample T test. Based on the results of service activities at Al Furqan Pharmacy Vocational School in Banjarmasin, it shows that the p-value $(0,000)<\alpha(0.05)$ which means that there is a statistically significant difference in knowledge between before and after counseling using power point media, it is concluded that the counseling method uses power point media conducted at the Al Furqan Pharmacy Vocational School in Banjarmasin capable and successfully effectively increasing student knowledge about "Specific Nutrition as a movement the First 1000 Days of Life in Preventing efforts of Stunting in children under five years.
\end{abstract}

Keywords: children under five years stunting, student knowledge, specific nutrition

\begin{abstract}
Abstrak
Kegiatan pengabdianini bertujuan untuk mentransformasi dan meningkatkan pengetahuan siswi mengenai gizi spesifik dalam 1000 Hari Pertama Kehidupan. Metode penyuluhan dilaksanakan dengan dua metode yaitu metode ceramah dan metode diskusi menggunakan media power poin, sebelum memulai penyuluhan, dilakukan kegiatan pretest mengenai "Gizi Spesifik dalam 1000 Hari Pertama Kehidupan", kemudian setelah diberikan penyuluhan, maka dibagikan kembali kuesioner tersebut untuk diisi kembali oleh siswi, setelah data pengetahuan sebelum dan sesudah penyuluhan sudah didapatkan, maka dianalisis menggunakan uji statistik Paired Sample T test. Berdasarkan hasil kegiatan pengabdian di SMK Farmasi Al Furqan kota Banjarmasin menunjukkan bahwa $p$-value $(0,000)<\alpha(0,05)$ yang artinya secara statistik terdapat perbedaan pengetahuan yang bermakna antara sebelum dan sesudah penyuluhan menggunakan media power point, disimpulkan bahwa metode penyuluhan menggunakan media power point yang dilakukan di SMK Farmasi Al Furqan kota Banjarmasin mampu dan berhasil secara efektif meningkatkan pengetahuan siswi mengenai "Gizi Spesifik Sebagai Gerakan 1000 Hari Pertama Kehidupan Dalam Upaya Pencegahan Stunting Balita”.
\end{abstract}

Kata Kunci: gizi spesifik, pengetahuan siswi, stunting balita

\section{PENDAHULUAN}

Stunting (kerdil) adalah kondisi dimana balita memiliki panjang atau tinggi badan yang kurang jika dibandingkan dengan umur. Kondisi ini diukur dengan panjang atau tinggi badan yang lebih dari minus dua standar deviasi median standar pertumbuhan anak dari WHO. Balita stunting termasuk masalah gizi kronik yang disebabkan oleh banyak faktor seperti kondisi sosial ekonomi, gizi ibu saat hamil, kesakitan pada bayi, dan kurangnya asupan gizi pada bayi. Balita stunting di masa yang akan datang akan mengalami kesulitan dalam mencapai perkembangan fisik dan kognitif yang optimal (Pusdatin Kemenkes RI, 2018).

Kejadian balita pendek atau biasa disebut dengan stunting merupakan salah 
satu masalah gizi yang dialami oleh balita di dunia saat ini. Pada tahun 2017 sebesar $22,2 \%$ atau sekitar 150,8 juta balita di dunia mengalami stunting. Namun angka ini sudah mengalami penurunan jika dibandingkan dengan angka stunting pada tahun 2000 yaitu sebesar 32,6\%. Pada tahun 2017, lebih dari setengah balita stunting di dunia berasal dari Asia sebesar $55 \%$ sedangkan lebih dari sepertiganya atau sebesar $39 \%$ tinggal di Afrika. Dari 83,6 juta balita stunting di Asia, proporsi terbanyak berasal dari Asia Selatan sebesar 58,7\% dan proporsi paling sedikit di Asia Tengah sebesar 0,9\%. Data prevalensi balita stunting yang dikumpulkan World Health Organization (WHO), Indonesia termasuk ke dalam negara ketiga dengan prevalensi tertinggi di regional Asia Tenggara/South-East Asia Regional (SEAR). Rata-rata prevalensi balita stunting di Indonesia tahun 2005-2017 sebesar 36,4\% (Pusdatin Kemenkes RI, 2018).

Stunting merupakan salah satu target Sustainable Development Goals (SDGs) yang termasuk pada tujuan pembangunan berkelanjutan ke-2 yaitu menghilangkan kelaparan dan segala bentuk malnutrisi pada tahun 2030 serta mencapai ketahanan pangan. Target yang ditetapkan adalah menurunkan angka stunting hingga $40 \%$ pada tahun 2025.

Berdasarkan Hasil Riset Kesehatan Dasar (Riskesdas) pada tahun 2018 angka stunting mengalami penurunan prevalensi di tingkat nasional sebesar $6,4 \%$ selama periode 5 tahun, yaitu dari 37,2\% (2013) menjadi $30,8 \%$ (2018). Sedangkan untuk balita berstatus normal terjadi peningkatan dari $48,6 \%$ (2013) menjadi 57,8\% (2018). Kendati sudah ada penurunan, Indonesia masih menjadi negara dengan anak berstatus gizi buruk. Sebab, saat ini gizi balita di Indonesia berada di bawah standar yang ditetapkan World Heatlh Organization (WHO) yakni di bawah 10\%. Berdasarkan Riskesdas 2018 sebanyak 2 provinsi mempunyai prevalensi stunting di atas $40 \%$, yang tergolong sangat tinggi, 18 provinsi mempunyai prevalensi stunting antara 30-40 $\%$ yang tergolong tinggi.

Dalam rangka mengatasi permasalahan gizi tersebut diatas, maka salah satu prioritas pembangunan kesehatan Indonesia dalam Rencana Pembangunan Jangka Menengah Nasional (RPJMN) tahun 2015-2019 adalah perbaikan gizi khususnya stunting. Pencapaian Indonesia dalam meningkatkan pertumbuhan ekonomi dan pemerataan pembangunan belum diikuti dengan peningkatan status kesehatan terutama pada balita, ibu hamil, dan remaja putri. Masalah gizi seperti gizi buruk dan stunting masih menjadi persoalan besar yang perlu diatasi segera. Stunting adalah kondisi gagal tumbuh pada anak balita akibat kekurangan gizi kronis terutama dalam 1000 Hari Pertama Kehidupan (HPK). Data Riset Kesehatan Dasar (Riskesdas) tahun 2013 menunjukkan bahwa satu dari tiga anak balita di Indonesia mengalami masalah stunting. Permasalahan gizi ini terjadi di hampir seluruh wilayah Indonesia dan tidak hanya terjadi pada kelompok penduduk miskin tetapi juga pada kelompok kaya (Pusdatin Kemenkes RI, 2018).

Dalam rangka percepatan perbaikan gizi, pemerintah telah mengeluarkan Peraturan Presiden nomor 42 tahun 2013 tentang Gerakan Nasional Percepatan Perbaikan Gizi yang fokus pada 1.000 Hari Pertama Kehidupan (HPK). Gerakan ini mengedepankan upaya bersama antara pemerintah dan masyarakat, melalui penggalangan partisipasi dan kepedulian pemangku kepentingan secara terencana dan terkoordinasi. Stunting terjadi karena kekurangan gizi kronis yang disebabkan oleh kemiskinan dan pola asuh tidak tepat, yang mengakibatkan kegagalan pertumbuhan, kemampuan kognitif tidak berkembang maksimal, mudah sakit dan berdaya saing rendah, sehingga bisa terjebak dalam kemiskinan. Periode 1000 HPK yang dimulai sejak janin dalam kandungan hingga anak berusia 2 tahun adalah masa kritis yang menentukan masa depan seorang anak. 
Dampak buruk kekurangan gizi pada periode 1000 HPK akan sangat sulit diperbaiki (Kesmas, Kemenkes RI, 2018).

Gerakan perbaikan gizi pada 1000 hari pertama kehidupan atau Gerakan 1000 HPK merupakan upaya Pemerintah dalam perbaikan gizi anak. Periode ini disebut golden periode atau waktu yang kritis dimana jika tidak dimanfaatkan dengan baik dapat menyebabkan kerusakan yang bersifat permanen. Indikator yang menjadi tujuan dari gerakan 1000 HPK adalah menurunkan jumlah BBLR, stunting, wasting, overweight, anemia, meningkatkan ASI eksklusif selama 6 bulan (Menkokesra RI, 2012 dalam Nefy dkk, 2019).

Menurut Peraturan Menteri Kesehatan Nomor 97 Tahun 2014 tentang Pelayanan Kesehatan Masa sebelum Hamil, Masa Hamil, Persalinan, dan Masa sesudah Melahirkan, Penyelenggaraan Pelayanan Kontrasepsi, serta Pelayanan Kesehatan Seksual, faktor-faktor yang memperberat keadaan ibu hamil adalah terlalu muda, terlalu tua, terlalu sering melahirkan, dan terlalu dekat jarak kelahiran. Usia kehamilan ibu yang terlalu muda (di bawah 20 tahun) berisiko melahirkan bayi dengan berat lahir rendah (BBLR). Bayi BBLR mempengaruhi sekitar 20\% dari terjadinya stunting (Pusdatin Kemenkes RI, 2018).

Menurut data Survei Sosial Ekonomi Nasional (SUSENAS) tahun 2017, hasil survei pada perempuan berumur 15-49 tahun diketahui bahwa $54,01 \%$ hamil pertama kali pada usia di atas 20 tahun (usia ideal kehamilan). Sisanya sebesar $23,79 \%$ hamil pertama kali pada usia 19-20 tahun, $15,99 \%$ pada usia $17-18$ tahun, dan $6,21 \%$ pada usia 16 tahun ke bawah. Hal ini menunjukkan bahwa setengah dari perempuan yang pernah hamil di Indonesia mengalami kehamilan pertama pada usia muda atau remaja. Kondisi ibu sebelum masa kehamilan baik postur tubuh (berat badan dan tinggi badan) dan gizi merupakan salah satu faktor yang mempengaruhi terjadinya stunting. Remaja putri sebagaicalon ibu di masa depan seharusnya memiliki status gizi yang baik. Pada tahun 2017, persentaseremaja putri dengan kondisi pendek dan sangat pendek meningkat dari tahun sebelumnya, yaitu7,9\% sangat pendek dan 27,6\% pendek.Dari sisi asupan gizi, 32\% remaja putri di Indonesia pada tahun 2017 berisiko kekurangan energykronik (KEK). Sekitar 15 provinsi memiliki persentase di atas rata-rata nasional. Jika gizi remajaputri tidak diperbaiki, maka di masa yang akan datang akan semakin banyak calon ibu hamil yang memiliki postur tubuh pendek dan/atau kekurangan energi kronik. Hal ini akan berdampak pada meningkatnya prevalensi stunting di Indonesia (Pusdatin Kemenkes RI, 2018).

Berdasarkan World Health

Organization Stunting dapat berawal dari Kondisi gizi ibu hamil, bahkan sebelum hamil akan menentukan pertumbuhan janin. Ibu hamil yang kekurangan gizi akan berisiko melahirkan bayi dengan berat lahir rendah, dan ini merupakan penyebab utama stunting. Setelah lahir, bayi yang tidak disusui secara baik akan berisiko menderita berbagai infeksi penyakit karena pola makan yang tidak cukup asupan gizinya dan tidak higienis. Pemberian Makanan Bayi dan Anak sangat menentukan petumbuhan anak. Setelah usia 6 bulan anak perlu mendapat asupan gizi dapat memenuhi kebutuhan asupan gizi mikro, gizi makro serta aman (Putri, 2012).

Pemerintah menetapkan stunting sebagai salah satu program prioritas. Berdasarkan Peraturan Menteri Kesehatan Nomor 39 Tahun 2016 tentang Pedoman Penyelenggaraan Program Indonesia Sehat dengan Pendekatan Keluarga, upaya yang dilakukan untuk menurunkan prevalensi stunting di antaranya adalah Intervensi pada 1.000 hari pertama kehidupan pada ibu hamil dan bersalin.

Perlunya edukasi kepada remaja putri atau calon ibu mengenai pentingnya 1.000 Hari Pertama Kehidupan (HPK), karena dengan pemahaman remaja putri mengenai pentingnya 1.000 Hari Pertama Kehidupan 
(HPK) sedini mungkin, maka akan memudahkan petugas kesehatan dalam memberikan intervensi pada saat remaja putri tersebut sudah menjadi seorang ibu.

Intervensi pada 1.000 hari pertama kehidupan yaitu upaya penurunan stunting dilakukan melalui dua intervensi, yaitu intervensi gizi spesifik untuk mengatasi penyebab langsung dan intervensi gizi sensitif untuk mengatasi penyebab tidak langsung, dimana intervensi gizi spesifik merupakan kegiatan yang langsung mengatasi terjadinya stunting seperti asupan makanan, infeksi, status gizi ibu, penyakit menular, dan kesehatan lingkungan. intervensi spesifik ini umumnya diberikan oleh sektor kesehatan (Bappenas RI, 2018).

Kerangka pertama adalah Intervensi Gizi Spesifik yang merupakan intervensi yang ditujukan kepada anak dalam 1.000 Hari Pertama Kehidupan (HPK) dan berkontribusi pada $30 \%$ penurunan stunting. Kerangka kegiatan intervensi gizi spesifik umumnya dilakukan pada sektor kesehatan. Intervensi ini juga bersifat jangka pendek dimana hasilnya dapat dicatat dalam waktu relatif pendek. Kegiatan yang idealnya dilakukan untuk melaksanakan Intervensi Gizi Spesifik dapat dibagi menjadi beberapa intervensi utama yang dimulai dari masa kehamilan ibu hingga melahirkan balita (TNP2K, 2017).

Oleh sebab itu, maka perlunya melakukan pengabdian kepada masyarakat dilakukan yang berjudul "Edukasi Gizi Spesifik Sebagai Gerakan 1000 Hari Pertama Kehidupan (HPK) Dalam Upaya Pencegahan Stunting Balita Pada Siswi di SMK Farmasi Al Furqan Banjarmasin Tahun 2019"

\section{TARGET DAN LUARAN}

Target dalam pengabdian ini adalah meningkatkan pengetahuan siswi mengenai gizi spesifik pada 1000 Hari Pertama
Kehidupan (HPK) dalam upaya pencegahan stunting pada balita sedangkan luarannya adalah publish ke jurnal pengabdian masyarakat.

\section{METODE PELAKSANAAN}

Mekanisme sebelum pelaksanaan penyuluhan terdiridari tahap persiapan yaitu penyusunanpreplanning, kontrak waktu\& menyepakati tempatpenyuluhan serta mempersiapan media penyuluhan. Metode penyuluhan yang dilaksanakan yaitu dengan menggunakan media power poin dalam penyampaian materi mengenai"Edukasi Gizi Spesifik Sebagai Gerakan 1000 Hari Pertama Kehidupan (HPK) Dalam Upaya Pencegahan Stunting Pada Balita". Tujuan dari kegiatan pengabdian ini adalah untuk mentransformasi dan meningkatkan pengetahuan siswi mengenai pentingnya Gizi Spesifik Sebagai Gerakan 1000 Hari Pertama Kehidupan (HPK) dalam upaya pencegahan stunting pada balita. Pelaksanaan pengabdian dilaksanakan pada tanggal 6 Januari 2020. Metode penyuluhan dilaksanakandengan dua metode yaitu metode ceramah dan metode diskusi menggunakan media power poin, sebelum memulai penyuluhan, dilakukan kegiatan pretest yaitu pengisian kuesioner oleh siswi untuk mengukur atau mengetahui sejauh mana pengetahuan siswi mengenai "Gizi Spesifik Sebagai Gerakan 1000 Hari Pertama Kehidupan (HPK) dalam upaya pencegahan stunting pada balita", kemudian setelah diberikan penyuluhan, maka dibagikan kembali kuesioner tersebut untuk diisi kembali oleh siswi.

\section{HASIL DAN PEMBAHASAN}

Pelaksanaan Kegiatan pengabdian kepada masyarakat dirincikan sebagai berikut 

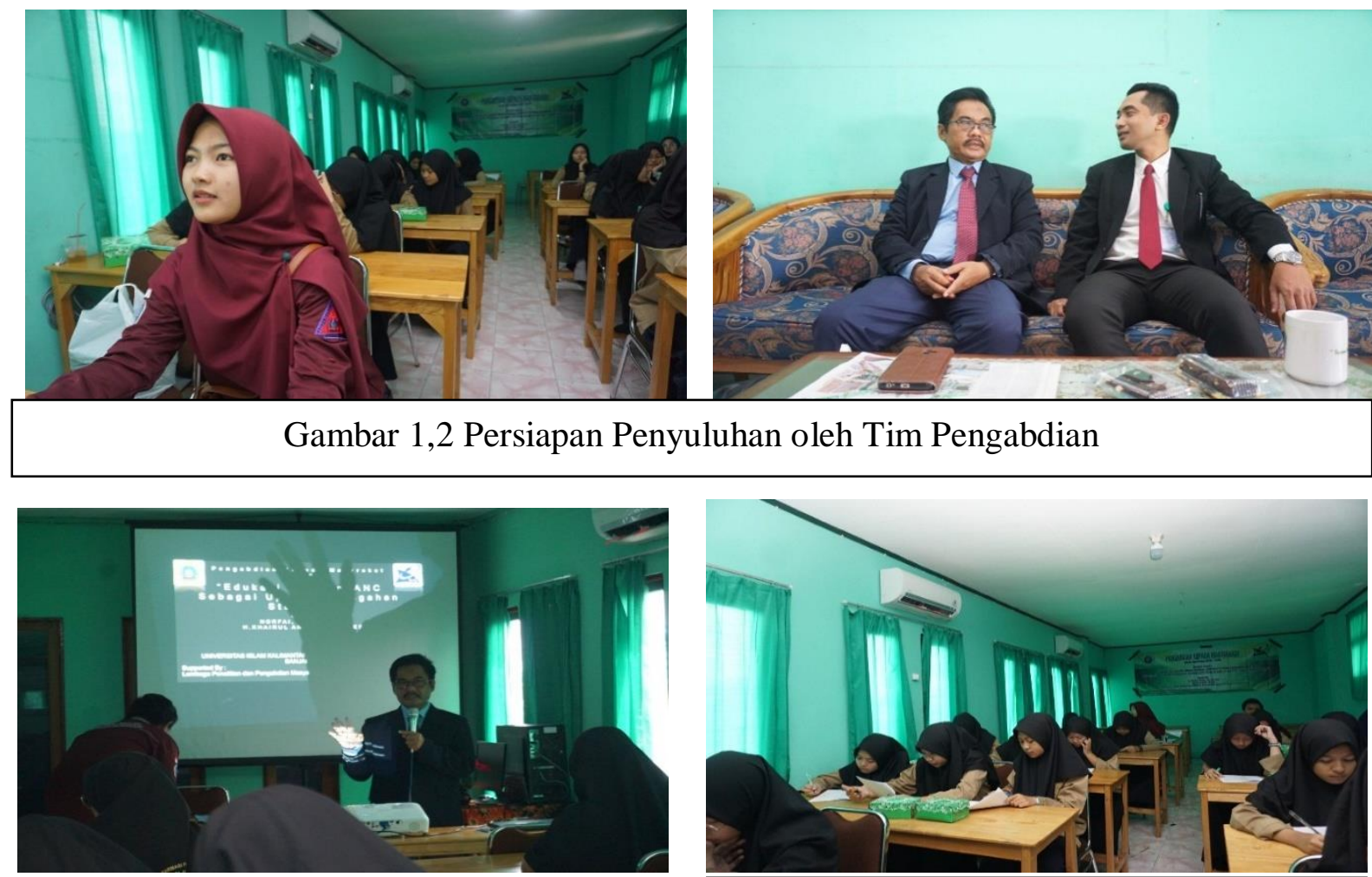

Gambar 1,2 Persiapan Penyuluhan oleh Tim Pengabdian

Gambar 3. Perkenalan dan Penjelasan Pretest

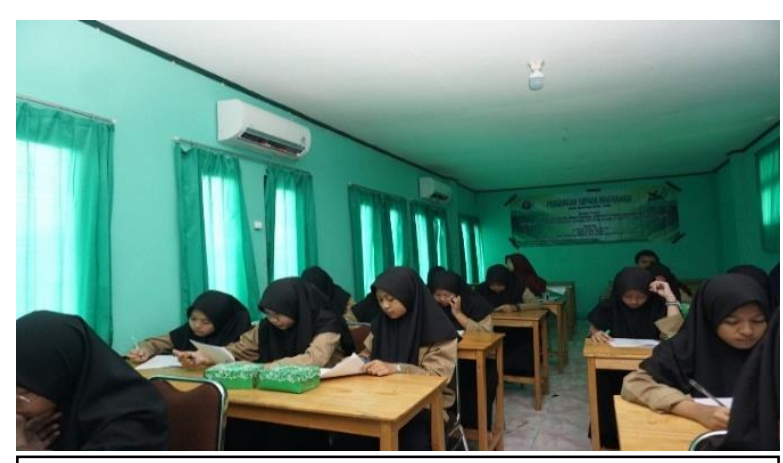

Gambar 4. Kegiatan Pretest

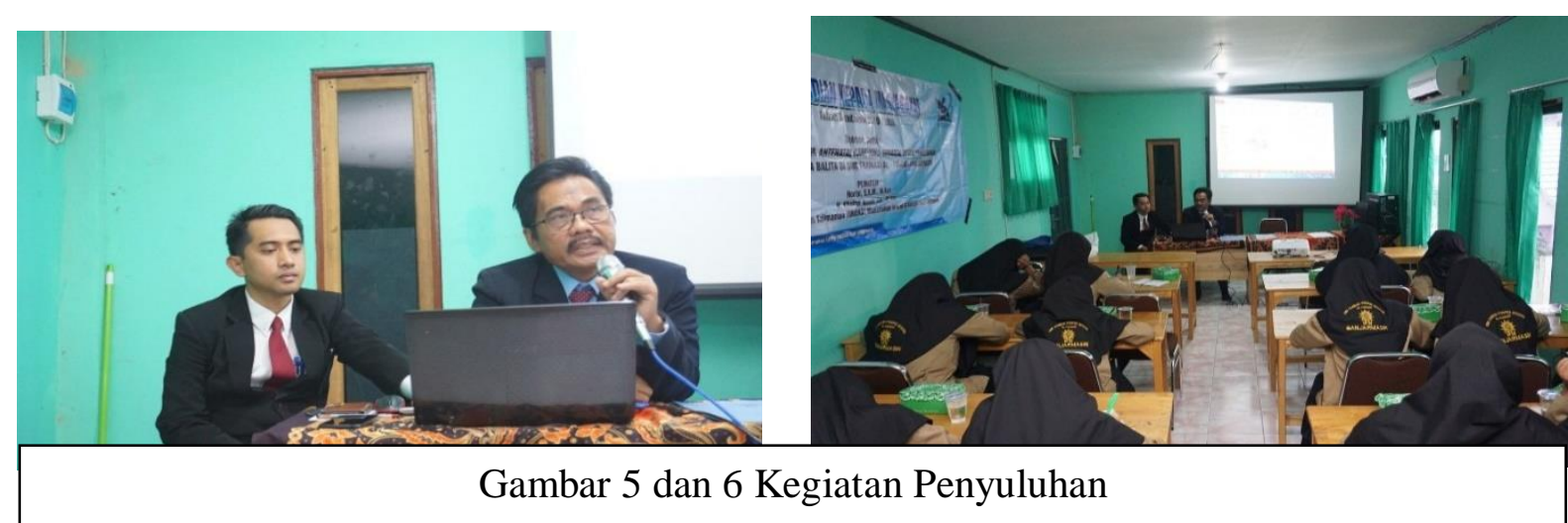

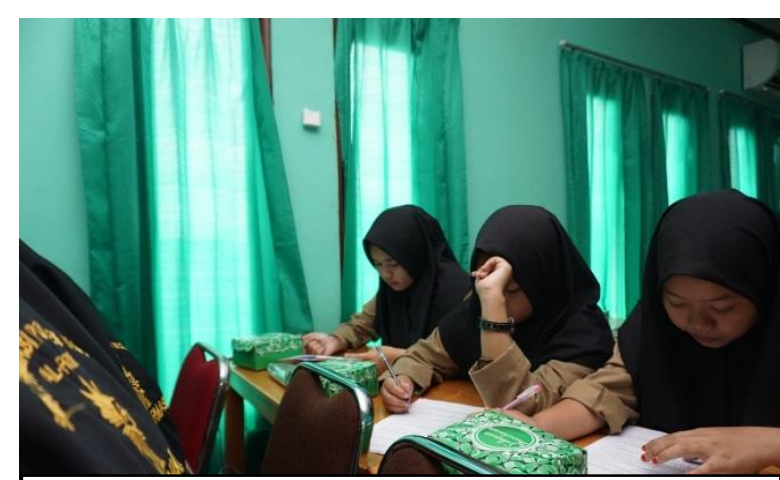

Gambar 7. Kegiatan Posttest

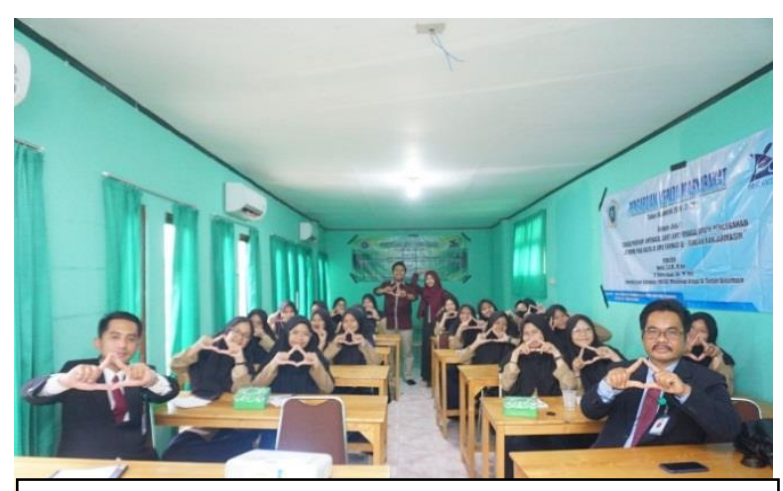

Gambar 8. Foto Bersama 
Tabel 1. Analisis Univariat

\begin{tabular}{clcc}
\hline No. & \multicolumn{1}{c}{ Variabel } & n & \% \\
\hline 1. & Pengetahuan (Pretest) & & \\
& Cukup & 3 & 15 \\
& Kurang & 17 & 85 \\
\cline { 2 - 4 } & Jumlah & 20 & 100 \\
\hline 2. & Pengetahuan (Posttest) & & \\
& Baik & 16 & 80 \\
& Cukup & 4 & 20 \\
\cline { 2 - 4 } & Jumlah & 20 & 100 \\
\hline
\end{tabular}

Berdasarkan pelaksanaan kegiatan pengabdian kepada masyarakat yang telah dilakukan di SMK Farmasi Al Furqan Kota Banjarmasin didapatkan perubahan pengetahuan yang bermakna mengenai "Edukasi Gizi Spesifik Sebagai Gerakan 1000 Hari Pertama Kehidupan (HPK) dalam upaya pencegahan stunting pada balita"yang dapat dilihat dari hasil pretest dan posttest mengunakan kuesioner, kemudian dianalisis menggunakan uji statistik Paired Sample T Test dengan alat bantu program komputer. Hasil analisis diperoleh bahwa $p$ value $(0,000)<\alpha(0,05)$ yang artinya secara statistik adanya perbedaan pengetahuan yang bermakna antara sebelum dan sesudah penyuluhan menggunakan media power point, dengan demikian disimpulkan bahwa metode penyuluhan menggunakan media power point yang dilakukan di SMK Farmasi Al Furqan Kota Banjarmasin mampu dan berhasil meningkatkan pengetahuan siswi mengenai "Gizi Spesifik Sebagai Gerakan 1000 Hari Pertama Kehidupan (HPK) Dalam Upaya Pencegahan Stunting Pada Balita", serta adanya kenaikan rerata skor pengetahuan sebelum dan sesudah penyuluhan yaitu dari rata-rata skor pengetahuan sebelum penyuluhan sebesar 8,60 menjadi sebesar 16,80 sesudah penyuluhan. Skor pengetahuan minimum yang didapatkan sebelum penyuluhan sebesar 6 sedangkan sesudah penyuluhan sebesar 12, dan skor pengetahuan maksimum yang didapatkan sebelum penyuluhan sebesar 13 sedangkan sesudah penyuluhan sebesar 20 .
Semua data statistik ini telah membuktikan bahwa media power point telah mampu dan berhasil secara efektif dalam memberikan pemahaman materi yang telah disampaikan, karena pada dasarnya media power point adalah alat dalam membatu proses pembelajaran yang dapat menciptakan suasana pembelajaran menjadi interaktif.

Sejalan dengan hasil penelitian yang dilakukan oleh Putri (2016) menunjukkan bahwa sebelum dilakukan penyuluhan dengan media power point diperoleh nilai rata-rata pengetahuan 7,5 dengan SD 1,43. Nilai terkecil yang diperoleh responden sebelum dilakukan penyuluhan dengan media power point hanya mencapai 5 poin dan nilai terbesar 10 poin, dan setelah dilakukan penyuluhan dengan media power point nilai rata-rata pengetahuan meningkat menjadi 13,20 dengan SD 1,42, dan nilai terkecil yang diperoleh siswa adalah 11 poin dan nilai terbesar mencapai 15 poin.

Hasil penelitian ini sesuai dengan teori yang dikemukakan oleh Sadiman dkk, (2002) dalam Sulistyawati (2014) yang menyatakan bahwa slide power point adalah suatu multimedia yang merupakan alat bantu visual yang biasa digunakan untuk bermacammacam bentuk media antara lain teks, grafik, gambar dan lain-lain sehingga proses pengajaran lebih interaktif. Hasil penelitian yang dilakukan oleh Wijayanti dkk (2016) menyatakan bahwa penyuluhan berupa ceramah dengan power point menggunakan media LCD berhasil meningkatkan pengetahuan masyarakat tentang leptospirosisdi Kecamatan Tembalang, Kota Semarang Jawa Tengah.

Berdasarkan penelitian yang dilakukan oleh Wasludin (2019) menyatakan bahwa nilai rata-rata pengetahuan dengan media elektronik lebih tinggi dibadingkan dengan nilai rata-rata pengetahuan dengan media cetak. Hasil uji statistik terhadap nilai pengetahuan sebelum dan sesudah penyuluhan kesehatan dengan media elektronik diperoleh nilai $\mathrm{p}=0,000$, 
maka disimpulkan terdapat perbedaan yang signifikan antara nilai pengetahuan sebelum dan sesudah dilakukan penyuluhan kesehatan dengan menggunakan media elektronik.

Media penyuluhan adalah semua sarana atau upaya untuk menampilkan pesan informasi yang ingin disampaikan oleh komunikator sehingga sasaran dapat meningkat pengetahuannya yang akhirnya diharapkan dapat berubah perilakunya ke arah positif terhadap kesehatan. Penyuluhan kesehatan tak dapat lepas dari media karena melalui media, pesan yang disampaikan dapat lebih menarik dan dipahami, sehingga sasaran dapat mempelajari pesan tersebut sehingga sampai memutuskan untuk mengadopsinya ke perilaku yang positif (Effendy, 2003 dalam Putri, 2016).

Media sangat diperlukan dalam pelaksanaan promosi kesehatan karena media dapat mempermudah penyampaian informasi dan dapat menghindari kesalahan persepsi. Belajar dengan menggunakan indera ganda (pandang dan dengar) akan memberikan keuntungan jika dibandingkan dengan memberikan materi yang disajikan hanya dengan stimulus pandang atau dengar (Arsyad, 2004).

Media merupakan salah satu faktor penentu keberhasilan pembelajaran. Melalui media proses pembelajaran bisa lebih menarik dan menyenangkan (joyfull learning). Aspek penting lainnya penggunaan media adalah membantu memperjelas pesan pembelajaran. Informasi yang disampaikan secara lisan terkadang tidak dipahami sepenuhnya, terlebih apabila kurang cukup dalam menjelaskan materi. Disinilah peran media, sebagai alat bantu memperjelas pesan pembelajaran (Hamtiah,2012 dalam Priyani, 2015).

Media sebagai alat bantu dalam proses belajar mengajar adalah suatu kenyataan yang tidak dapat dipungkiri. Alat bantu atau media sangat penting ketika dipergunakan untuk penyuluhan, karena alat bantu digunakan oleh pendidik dalam menyampaikan bahan pendidikan atau pengajaran (Astoeti, 2006 dalam Prasko, dkk 2016).

Power Point adalah salah satu program Microsoft Office, dimana program aplikasi yang dirancang secara khusus untuk menampilkan program multimedia. Menurut Riyana (2008) menyatakan bahwa program Microsoft Office Power Point adalah salah satusoftware yang dirancang khusus untuk mampu menampilkan program multimedia dengan menarik, mudah dalam pembuatan, mudah dalam penggunaan dan relatif murah karena tidak membutuhkan bahan baku selain alat untuk menyimpan data. Slide Power Point adalah suatu multimedia yang merupakan alat bantu visual yang bisa digunakan untuk bermacam-macam bentuk media seperti teks, gambar, grafik dan lainlain sehingga proses pengajaran lebih interaktif (Arsyad, 2004).

Faedah penggunaan media yakni mendorong keinginan orang untuk mengetahui, kemudian lebih mendalami, dan akhirnya memberikan pengertian yang lebih baik (Mahfoedz, 2007 dalam Wijayanti, dkk., 2016). Green dan Kreuter menyatakan bahwa pengetahuan adalah suatu hasil dari tahu, yang terjadi setelah individu melakukan penginderaan terhadap objek tertentu. Hasil dan bukti belajar adalah adanya perubahan dari tidak tahu menjadi tahu, dan dari tidak mengerti menjadi mengerti. Keberhasilan (Nurlaela, 2014 dalam Wijayanti, dkk., 2016).

Berdasarkan hasil penelitian yang ditelah didapatkan, serta membandingkan hasil penelitian yang sebelumnya serta teori yang telah dikemukakan telah membuktikan bahwa penggunaan media, khususnya media power point efektif dalam memudahkan pemahaman mengenai materi yang disampaikan kepada objek sasaran yang dapat dilihat dari hasil statistik yaitu adanya kenaikan rerata skor pengetahuan sebelum dan sesudah penyuluhan pada siswi di SMK Farmasi Al Furqan kota Banjarmasin yaitu rata-rata skor pengetahuan sebelum 
penyuluhan sebesar 8,60 menjadi sebesar 16,80 sesudah penyuluhan dilakukan, adanya kenaikan yang bermakna rerata skor pengetahuan sebagai indikator keberhasilan dalam kegiatan penyuluhan yang telah dilakukan, selain itu juga adanya bentuk apresiasi dan tanggapan yang positif dari siswi serta pihak sekolah mengenai kegiatan penyuluhan "Gizi Spesifik Sebagai Gerakan 1000 Hari Pertama Kehidupan (HPK) Dalam Upaya Pencegahan Stunting Pada Balita”.

\section{KESIMPULAN DAN SARAN}

\section{Kesimpulan}

Berdasarkan hasil kegiatan pengabdian di SMK Farmasi Al Furqan kota Banjarmasin menunjukkan bahwa p-value $(0,000)<\alpha$ $(0,05)$ yang artinya secara statistik terdapat perbedaan pengetahuan yang bermakna antara sebelum dan sesudah penyuluhan menggunakan media power point, dengan demikian dapat disimpulkan bahwa metode penyuluhan menggunakan media power point yang dilakukan di SMK Farmasi Al Furqan kota Banjarmasin mampu dan berhasil secara efektif meningkatkan pengetahuan siswi mengenai "Gizi Spesifik Sebagai Gerakan 1000 Hari Pertama Kehidupan (HPK) Dalam Upaya Pencegahan Stunting Pada Balita".

\section{Saran}

Disarankan setiap petugas kesehatan dalam memberikan penyuluhan kesehatan untuk dapat menggunakan dan mengoptimalkan media dalam kegiatan penyuluhan, salah satunya yaitu menggunakan media power point yang dapat membantu subjek sasaran memahami materi yang disampaikan.

\section{DAFTAR PUSTAKA}

Arsyad, A., $2004 . \quad$ Media Pembelajaran.Jakarta: Raja Grafindo

Badan Penelitian dan Pengembangan Kesehatan (Balitbangkes), Kemenkes RI., 2013. Riset Kesehatan Dasar (RISKESDAS 2013). Jakarta : Balitbangkes Kemenkes RI. [Online]. http://www.depkes.go.id/resources/do
wnload/general/Hasil\%20Riskesdas\% 202013.pdf. [diakses tanggal 20 September 2019].

Badan Penelitian dan Pengembangan Kesehatan (Balitbangkes), Kemenkes RI., 2018. Riset Kesehatan Dasar (RISKESDAS 2018). Jakarta : Balitbangkes Kemenkes RI.[Online]. http://www.depkes.go.id/resources/do wnload/info-

terkini/materi_rakorpop_2018/Hasil\% 20Riskesdas\%202018.pdf. [diakses tanggal 20 September 2019].

Badan Perencanaan dan Pembangunan Nasional (Bappenas), 2018. Pedoman Pelaksanaan : Intervensi Penurunan Stunting Terintegrasi di Kabupaten/Kota. Edisi November $2018 . \quad$ [Online]. http://tnp2k.go.id/filemanager/files/R akornis\%202018/Pedoman\%20Pelaks anaan $\% 20$ Intervensi\%20Penurunan $\%$ 20Stunting\%20Terintegrasi\%20Di\%2 0Kabupaten\%20Kota.pdf. [diakses tanggal 14 September 2019].

Kesmas, Kementerian Kesehatan, 2018. Panduan Kegiatan Peringatan Hari Gizi Nasional Ke-58 Tahun 2018 :"Mewujudkan Kemandirian Keluarga dalam 1000 Hari Pertama Kehidupan (HPK) untuk Pencegahan Stunting”.

[Online].http://www.kesmas.kemkes. go.id/assets/upload/dir_519d41d8cd9 8f00/files/Panduan-HGN-

2018_966.pdf. [diakses tanggal 20 September 2019].

Nefy, Nesra., Lipoeto, Nur Indrawati dan Edison., 2019. Media Gizi Indonesia. Implementasi Gerakan 1000 Hari Pertama Kehidupan di Kabupaten Pasaman 2017. Vol. 14, No. 2. [Online]. https://ejournal.unair.ac.id/MGI/article/view/1 1140. [diakses tanggal 20 September 2019].

Pusat Data dan Informasi (Pusdatin), Kemenkes RI., 2018. Buletin Jendela 
Data dan Informasi Kesehatan : Situasi Balita Pendek (Stunting) di Indonesia. Semester I 2018. Jakarta : Pusdatin Kemenkes 2018. [Online].www.depkes.go.id , download, pusdatin, buletin , Buletin-Stunting-2018. [diakses tanggal 20 September 2019].

Priyani, Elis Siti., 2015. Naskah Publikasi. Pengaruh Penyuluhan Media Powerpoint Dan Mediavideo Terhadap Tingkat Pengetahuan Ibu Tentang Kontrasepsi Iud Pasca Plasenta Di Puskesmas Kasihan I Bantul. Program Studi Bidan Pendidik Jenjang D IV Sekolah Tinggi Ilmu Kesehatan 'Aisyiyah Yogyakarta. [Online]. http://digilib.unisayogya.ac.id/431/1/

Naskah\%20publikasi.pdf. [diakses tanggal 3 Februari 2020].

Prasko, Sutomo, Bambang., Santoso, Bedjo., 2016. Jurnal Kesehatan Gigi. Penyuluhan Metode Audio Visual dan Demonstrasi Terhadap PengetahuanMenyikat Gigi pada Anak Sekolah Dasar. Vol. 03, No.2 Desember 2016. [Online].https://ejournal.poltekkessm g.ac.id/ojs/index.php/jkg/article/view File/1784/476. [diakses tanggal 4 Februari 2020].

Putri, A. 2012. Jurnal Kesehatan Masyarakat (JKM) Hubungan Tingkat Pendidikan Ibu, Pendapatan Keluarga, Kecukupan Protein dan Zinc dengan Stunting (Pendek) pada Balita Usia 6- 35 Bulan di Kecamatan Tembalang Kota Semarang. Vol.1, No. 2, GiziKesehatanMasyarakatFakultasKe sehatanMasyarakat,UniversitasDipon egoro.

Putri, Rindy Ayu., 2016. Tesis. Efektivitas Metode Ceramah Dengan Media Powerpoint Dan Leafletdalam Peningkatanpengetahuan Dan Sikap Wanita Usia Subur (Wus) Tentang Kanker Serviks Di Wilayah Kerja
Puskesmas Helvetia Kecamatan Medan Helvetia Tahun 2016. Program Studi S2 Ilmu Kesehatan Masyarakat Fakultas Kesehatan Masyarakat Universitas Sumatera Utara Medan. [Online]. http://repositori.usu.ac.id/bitstream/ha ndle/123456789/19548/147032015.pd f?sequence $=1$. [diakses tanggal 4 februari 2020].

Riyana, I., 2008. Pemanfaatan OHP dan Presentasi dalam Pembelajaran. Jakarta: Cipta Agung.

Sulistyawati, Nur Dani., 2014. Efektifitas Alat Bantu Penyuluhan Slide Power Pointdengan Leaflet tentang Kanker Servik Terhadap Sikap WUS dalamPemeriksaan IVA di Desa Jatimulyo Dlingo Bantul Tahun 2014. Program Studi Bidan Pendidik Jenjang D IV, Sekolah Tinggi Ilmu Kesehatan'Aisyiyah Yogyakarta. [Online]. Available from:http://digilib.unisayogya.ac.id/ 1128/1/NASKAH\%20PUBLIKASI. pdf.[diakses tanggal 4 Februari 2020].

Tim Nasional Percepatan Penanggulangan Kemiskinan (TNP2K), 2017. 100 Kabupaten/Kota Prioritas Untuk Intervensi Anak Kerdil (Stunting) : Ringkasan. Cetakan Pertama, Agustus 2017.

http://www.tnp2k.go.id/images/uploa ds/downloads/Buku\%20Ringkasan\%2 OStunting-1.pdf. [diakses tanggal 20 September 2019].

Wasludin, 2019. Jurnal Medikes (Media Infromasi Kesehatan). Efektifitas Media Elektronik Dan Media Cetak Terhadap Pengetahuan Hiv/Aids Pada Siswa Smp Negeri 4 Kota Tangerang. Vol. 6, No. 1. [Online]. https://jurnal.poltekkesbanten.ac.id/M edikes/article/view/90. [diakses tanggal 4 Februari 2020].

Wijayanti, Tri., Isnani, Tri., Kesuma, Agung Puja., 2016., BALABA : Jurnal 
Litbang Pengendalian Penyakit

Bersumber Binatang Banjarnegara.

Pengaruh Penyuluhan (Ceramah

dengan Power Point) terhadap

Pengetahuan tentang Leptospirosis di

Kecamatan Tembalang, Kota

Semarang Jawa Tengah. Vol. 12, No.
1, Juni 2016. [Online]. https://media.neliti.com/media/public ations/57729-ID-pengaruh-

penyuluhan-ceramah-dengan-

power.pdf. [diakses tanggal 4

Februari 2020]. 